\title{
Financial leverage and performance of SMEs in Vietnam: Evidence from the post-crisis period
}

\author{
Duy-Tung Bui ${ }^{1, *} \cdot$ Huan Huu Nguyen ${ }^{2} \cdot$ Vu Minh Ngo $^{2}$ \\ ${ }^{1}$ UEH Sustainable Finance Institute, University of Economics Ho Chi Minh City, Vietnam \\ ${ }^{2}$ University of Economics Ho Chi Minh City, Vietnam
}

Received: 4 September 2020

Revised:24 March 2021

Accepted: 25 March 2021

\begin{abstract}
This study examines the link between capital structure and firm performance (measured by ROA and ROE), focusing on a large sample of SMEs in Vietnam during the postcrisis period (2008-2016). SMEs are more exposed to risks than large firms and have very restricted access to external financing, thus limiting their growth and performance. Empirical results from various panel data models confirm the nonlinear relationship between debt financing and firm profitability. This relationship takes the form of an inverted-U shape. Firm profitability only increases to a certain level of leverage. When the debt ratio becomes too high, firm performance starts to decrease. These results highlight the role of financial distress costs in debt financing for SMEs. Furthermore, the paper also confirms the heterogeneity between state-owned firms and private ones. Policy implications are also discussed.
\end{abstract}

Keywords: SMEs; financial leverage; firm performance; debts financing; firm profitability JEL Classification Codes: G20, E43, E52

\section{Introduction}

Vietnam's economy has recently integrated into regional economic activities more aggressively, by liberalising its trade and investment, as well as participating in the Association of Southeast Asian Nations (ASEAN) Economic Community. This context promotes the creation and expansion of small and medium-sized enterprises (SMEs). Vietnam's SMEs strive to integrate their products in the international production networks, or global value chains.

Related literature also supports the role of SMEs in promoting economic growth across the globe (Li et al., 2019). Even in developed countries, governments continue to encourage the creation and growth of SMEs as they act as the main driver for economic growth and accumulating social wealth. The promotion and development of SMEs play an essential part in Vietnam's economic reform (Harvie, 2004). According to the General Statistics Office of Vietnam, till 2020, SMEs are accounted for $96.7 \%$ of the total number of companies and

\footnotetext{
*Corresponding author. E-mail: tungbd@ueh.edu.vn.
}

Citation: Bui, D. T., Nguyen, H. H., and Ngo, V. M. (2021) Financial leverage and performance of SMEs in Vietnam: Evidence from the post-crisis period, Economics and Business Letters, 10(3), 229-239.

DOI: 10.17811/ebl.10.3.2021.229-239 
more than $56 \%$ of revenue generated by all type of businesses in Vietnam. Given the fact that the reform of ineffective large state-owned enterprises will not be rewarded in the recent future, SMEs are the main drivers for economic transitions and sustainable economic growth in Vietnam.

This paper is related to the related literature in several aspects. First, despite their active role in promoting economic growth and integration, SMEs are more vulnerable to risk than largesize firms. Asymmetric information is prevalent in lending contracts between SMEs and banks (Li et al., 2019). Consequently, these financial barriers make external funding more difficult for SMEs. For example, previous literature documents that SMEs in Eastern European countries have limited access to the financial market (J oeveer, 2013). These financial constraints will prevent SMEs to grow and develop, thus making them more susceptible to failure. Moreover, recent research in emerging economies found that SMEs have an immense capacity to utilise resources and manufacture goods for the economy. However, they are lagged in innovations and growth due to the lack of long-term funding and human resources (Gunjati \& Adake, 2020).

Second, the difficulties of SMEs financing were more severe after the global financial crisis in 2007-2008 (GFC). According to Demirgüç-Kunt et al. (2020), SMEs in less efficient legal systems and less developed financial sectors as Vietnam deleveraged substantially in the period from 2008-2011. However, the cooperate debt level in emerging economies has been rising again and reach a new high in 2014 of 55 per cent of GDP (Herwadkar, 2017). The unstable of SEMs' debt leverage in emerging markets after the GFC raises the research question of whether there is an optimal capital structure for SMEs and how debt leverage affects SMEs' performance in the post-crisis period.

The term capital structure refers to the combination of debt securities and equity that a firm uses to finance its business (Abor, 2007). At first, Modigliani and Miller (1958) argue that the choice of funding does not affect firms' value. However, the assumptions of Modigliani and Miller (1958) are strong, and their validity is questionable. The fluctuation of the capital structure in emerging economies might follow the trade-off theory from Myers (1977) and Jensen and Meckling (1976) which posited the existence of firms' optimal capital structure. According to the trade-off theory, the tax shield benefit of debt -financing can help improve firms' profitability at low financial leverage ratios. However, as the debt ratio increases, financial distress costs surpass the benefits and firm performance decreases with increasing debts. Particularly in the sample of SMEs in Vietnam, the trade-off theory could explain the non-linear relationship between SMEs' financial leverage and profitability could be observed (see Figure 1).

On the empirical ground, several papers attempted to explore the firms' optimal capital structure hypothesis. For example, Cheng et al. (2010) find that the link between financial leverage and firm performance takes an inverted-U shape for a panel of 650 traded stocks in China from 2001-2006. The non-linearity is also found in Lin and Chang (2011) using a sample of 196 Taiwanese listed firms from 1993 - 2005. The positive effect only exists below a certain level of debt ratio. When the debt ratio becomes too high, the effect becomes insignificant. Regarding the general relationship between capital structure and firm performance, the evidence is still mixed and inconclusive. Several studies find positive impacts of debt financing on firm performance and profitability (V $\mathrm{V}^{\smile}$ atavu, 2015; Vithessonthi and Tongurai, 2015; Gonz'alez, 2013; Fosu et al., 2016; Abdullah and Tursoy, 2019), while others show negative impacts (Fosu, 2013; Margaritis and Psillaki, 2010; Ramli et al., 2019; Davydov, 2016; Ahmed and Afza, 2019).

In general, given the SMEs' fluctuated capital structure in the post-crisis period in emerging economies (Demirgüç-Kunt et al., 2020; Herwadkar, 2017) and the mixed results about the effects of capital structures on SEMs' performance ( Abdullah and Tursoy, 2019; Ahmed and 
Afza, 2019), this paper aims to extend the literature on the topic of the relationship between capital structure and SMEs' performance in several aspects. First, using a unique sample of about 4000 SMEs in Vietnam from 2008-2016, this study could examine the effects of GFC within the SMEs' leverage - profitability relationship.

Second, the heterogeneities of SMEs in their ownership structures (private and state-owned SMEs) are considered in this study as a factor that might explain the mixed results of the relationship between SMEs' leverage and profitability. Regarding the context of transitional economies such as Vietnam, the ownership structures could play an important role in firms' governance and performances (Guan et al., 2021). Finally, previous literature on Vietnamese firms (Vo and Ellis, 2017; Nguyen et al., 2014) tends to support the detrimental effect of debt financing on firm performance. As a new appROAch, we focus on the non-linearity in this study. The empirical results strongly support the existence of an optimal capital structure for SMEs in Vietnam. Hence, the following hypotheses are proposed:

H1: The relationship between SMEs' financial leverage and performance follows the quadratic non-linear function in the post-crisis period.

H2: Ownership structure in SMEs moderates the relationship between SMEs' financial leverage and performance.

The rest of the paper is structured as follows. Section 2 elaborates the empirical specification and the scope of the study, while Section 3 discusses the empirical results. Finally, Section 4 concludes the study.

\section{Data and methodology}

\subsection{Data}

In this paper, we use a sample of SMEs data collected from the Ho Chi Minh City Statistical Office from 2008 to 2016. SMEs with missing data and inconsistent financial reports will be filtered according to the following criteria: (1) firms with missing values in total assets or total liabilities; (2) firms with inaccurate financial statements, for example, the total assets are not equal to the total liabilities. As a result, the remaining dataset includes 4983 enterprises, with 1430 medium businesses and 3533 small businesses. In terms of ownership structure, there are 36 state-owned enterprises, 1646 private enterprises, 44 cooperatives, and the rest is of other types.

Table 1 shows the summary statistics of key variables and their definitions. Overall, the average ROA and ROE of Vietnam's SMEs are quite small, $0.5 \%$ and $0.7 \%$ respectively. This is because many SMEs realized considerable losses. Besides, the standard deviation of ROA and ROE is large, about 10 times compared to the average. Furthermore, the leverage variable also has a large divergence between the min and max value, $4.5 \%$ and $18.1 \%$ respectively.

\subsection{Empirical model and estimation method}

There are several proxies for firm performance in previous literature. For example, there are measures based on accounting ratios such as return on equity (ROE), return on assets (ROA) or gross margin ratio (Majumdar and Chhibber, 1999; Abor, 2005). Other authors prefer using market-based variables like stocks return or volatility or hybrid measures such as Tobin-Q. However, market-based measures for SMEs are generally not available. Therefore, the study employs two accounting-based measures as proxies for firm performance: ROE and ROA.

Figure 1 presents the relationship between firm performance, measured by ROA and ROE, and financial leverage. The fitted lines show nonlinear patterns representing the link between SMEs' profitability and debts ratios. The general pattern shows the profitability measures start to decrease faster when firms use more leverage, especially the plot of ROE and total leverage in the left panel. 
Table 1. Descriptive statistics. This table represents the descriptive statistics and the definitions of main variables in the sample data used in the study. ROA and ROE means are within the range from $0.5 \%-0.7 \%$. The average leverage level is about 2.7 which means, on average, debts were 2.7 times larger than equity in SMEs. However, the long-term leverage is only 0.752 indicating SMEs used mainly short-term debts for their operations.

\begin{tabular}{|c|c|c|c|c|c|}
\hline & mean & $\mathrm{sd}$ & $\min$ & $\max$ & Definition \\
\hline$\overline{\mathrm{ROA}}$ & 0.005 & 0.045 & -0.203 & 0.147 & $\begin{array}{l}\text { Return on total asset measured by the ratio } \\
\text { of net profit/total asset }\end{array}$ \\
\hline ROE & 0.007 & 0.181 & -2.461 & 0.980 & $\begin{array}{l}\text { Return on equity measured by the ratio of } \\
\text { net profit/equity }\end{array}$ \\
\hline leverage & 2.772 & 2.632 & 0.061 & 18.289 & $\begin{array}{l}\text { The SMEs' financial leverage measured by } \\
\text { the total debt/equity ratio }\end{array}$ \\
\hline lterm & 0.752 & 1.096 & 0.001 & 6.783 & $\begin{array}{l}\text { The SMEs' long-term financial leverage } \\
\text { measured by the long-term debt/equity ratio }\end{array}$ \\
\hline sterm & 2.020 & 2.303 & 0.004 & 12.808 & $\begin{array}{l}\text { The SMEs' short-term financial leverage } \\
\text { measured by the short-term debt/equity ratio }\end{array}$ \\
\hline GDPgrowth & 0.059 & 0.005 & 0.052 & 0.067 & $\begin{array}{l}\text { Annual Gross Domestic Product growth rate } \\
\text { of Vietnam from 2008-2016. }\end{array}$ \\
\hline size & 23.260 & 1.426 & 12.718 & 29.510 & $\begin{array}{l}\text { Size of SMEs, measured by the log of total } \\
\text { assets in billion VND }\end{array}$ \\
\hline class & 0.318 & 0.466 & 0.000 & 1.000 & $\begin{array}{l}\text { Dummy variables which received value of } 1 \\
\text { if the observation is state-owned SME, oth- } \\
\text { erwise, received value of } 0 .\end{array}$ \\
\hline crisis & 0.199 & 0.399 & 0.000 & 1.000 & $\begin{array}{l}\text { Dummy variables which received value of } 1 \\
\text { if the observation is in } 2008 \text { and } 2009 \text {, other- } \\
\text { wise, received value of } 0 .\end{array}$ \\
\hline
\end{tabular}

Figure 1. Firm performance and financial leverage.

ROE and capital structure

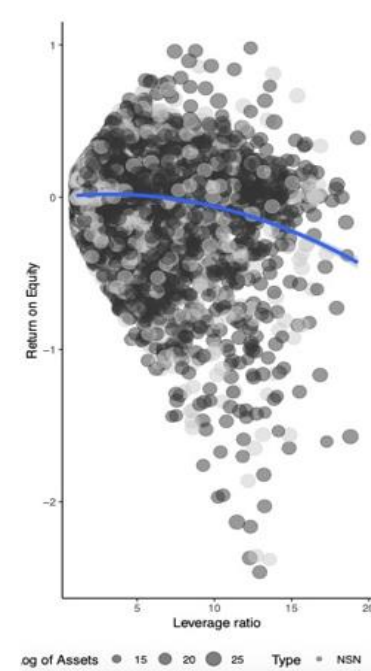

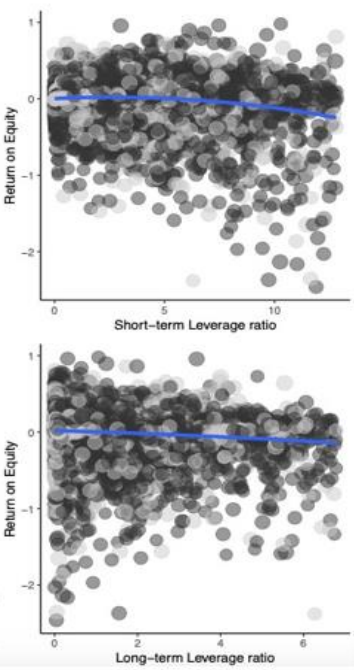

\section{ROA and capital structure}

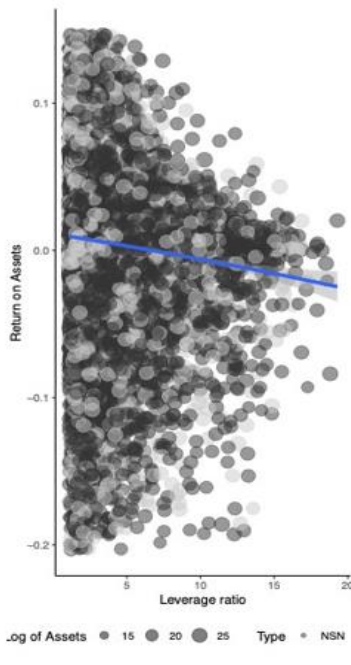

To determine the relationship between capital structure and firm performance, we regress the following model:

$$
\begin{aligned}
\text { Performance }_{i t} & =\beta_{0}+\rho \text { Performance }_{i t-1}+\beta_{1} \text { Leverage }_{i t}+\beta_{2} \text { Leverage }_{i t}^{2} \\
& +\sum_{j=1}^{K} \alpha_{j} \text { Control }_{j i t}+\mu_{i}+\epsilon_{i t}
\end{aligned}
$$


where Performance can be either ROE or ROA. For financial leverage, we use three following ratios: Total debts to equity, short-term debts to equity and long-term debts to equity. The paper also uses other firm-specific variables to control for firm's characteristics such as the firm's size and the firm's ownership classification. We control for the macROEconomic fluctuations by using the growth rate of GDP.

Equation (1) has the form of a dynamic panel data model, where the lag of the dependent variable appears on the left-hand side. Thus, endogeneity is present in our model. As a consequence, we use the GMM estimator, developed by Arellano and Bover (1995) and Blundell and Bond (1998). In particular, we use the two-step system GMM proposed by Blundell and Bond (1998) with the finite sample correction of variance-covariance matrix developed by Windmeijer (2005) to estimate Equation (1).

\section{Empirical results}

\subsection{Baseline results}

Before estimating the model, we use the correlation matrix to test the multicollinearity. The result in Table 2 shows that all the coefficients of correlation among the independent variables are under 0.8 . This table also suggests that financial leverage has a negative relationship with all performance measures, namely ROA and ROE.

We present the system GMM estimation results of Equation (1) in Table 3 where the total debts to equity ratio is used as a proxy for the capital structure. We report in columns (1) and (2) the results of the baseline model with ROA and ROE representing firm performance, respectively. In columns (3) and (4), we add the crisis dummy that controls for the crisis period. It takes value one if the year is 2008 or 2009 and zero otherwise.

To analyse the nonlinear effect of financial leverage on performance, we used the square of the leverage variable (leverage2). The results show that both leverage and leverage 2 are statistically significant. Furthermore, leverage is significantly positive, while leverage 2 is significantly negative. These results imply that the relationship between financial leverage and firm performance takes an inverted-U shape. It's consistent with Myers (1977), which confirms an optimal capital structure exists. With an optimal capital structure, the value of a business will be determined by offsetting the costs and benefits of debts. Therefore, SMEs' final performance will be equal to the difference between the present value of the tax benefit and the present value of agency and bankruptcy costs.

Regarding the estimation results for ROE, the findings are consistent with those of ROA. We find a threshold for the leverage effect on ROE. In low debt ratio levels, financial leverage has a positive impact on ROE. However, when the firms' debts ratio passes a certain threshold, using more debts hurts firm performance. This is because firms would have higher interest expenses and financial distress costs. These costs reduce firm performance and push them to the risk of bankruptcy (Myers, 1977; Myers and Majluf, 1984). Thereby the theory of optimal capital structure is confirmed for SMEs in Vietnam. For this sample, the optimal value of the capital structure is around three to four. H1 is supported.

Another finding in this study is the global financial crisis dummy is positively associated with SMEs performance. Small and medium-sized enterprises have a more flexible asset structure. They can quickly adapt to external shocks by expanding or narrowing their businesses. Besides, during 2007-2009, Vietnam's economy was not sufficiently integrated into the world economy. Thus, the impact of the crisis is not fatal, especially for SMEs, since these enterprises mostly concentrate on the domestic market.

\subsection{Heterogeneity among different ownership structures}

We divided the sample into two subsamples, one for state-owned enterprises and one for private enterprises to check the heterogeneity among different ownership types. The differences 
between the two samples such as ownership structure, capital, governance and functionality could lead to heterogeneity among the two groups. Columns (1) and (2) of Table 4 report the results for state-owned enterprises, while column (3) and (4) of this table show the results for private businesses.

Table 2. Correlation matrix. This table represents the correlation matrix between variables used in this paper. Most of the correlations values are in the sign expected and statistically significant.

\begin{tabular}{lrrrrrrr}
\hline \hline & $\boldsymbol{R O A}$ & $\boldsymbol{R O E}$ & leverage & lterm & sterm & GDPgrowth & size \\
\hline $\boldsymbol{R O A}$ & 1.00 & & & & & & \\
ROE & $0.81 * * *$ & 1.00 & & & & & \\
leverage & $-0.10 * * *$ & $-0.14 * * *$ & 1.00 & & & & \\
lterm & $-0.11 * * *$ & $-0.13 * * *$ & $0.49 * * *$ & 1.00 & & & \\
sterm & $-0.07 * * *$ & $-0.10 * * *$ & $0.91 * * *$ & $0.08 * * *$ & 1.00 & & \\
GDPgrowth & $0.01 *$ & $0.02 * * *$ & $0.02 * * *$ & $0.04 * * *$ & 0.01 & 1.00 & \\
size & $0.14 * * *$ & $0.13 * * *$ & $0.20 * * *$ & 0.01 & $0.22 * * *$ & $0.03 * * *$ & 1.00 \\
\hline \hline
\end{tabular}

Notes: ROA: return on total assets, ROE: return on equity, leverage: total debts to equity, lterm: long-term debts to equity, sterm: short-term debt to equity, gdpgrowth: growth rate of GDP, size: $\log$ of total assets, ${ }^{*} p<0.10$, ${ }^{* *} p<0.05,{ }^{* * *} p<0.01$.

Table 3. System GMM estimation results of Equation (1). In columns (1) and (2), ROA and ROE are regressed against their lag terms and total leverage levels. In columns (3) and (4), the dummy variable "crisis" was added to account for the time-event effects in the crisis period.

\begin{tabular}{|c|c|c|c|c|}
\hline & $\begin{array}{r}(1) \\
R O A \\
\end{array}$ & $\begin{array}{r}(2) \\
R O E \\
\end{array}$ & $\begin{array}{r}(3) \\
R O A \\
\end{array}$ & $\begin{array}{r}(4) \\
R O E \\
\end{array}$ \\
\hline L.ROA & $0.220 * * *$ & & $0.226 * * *$ & \\
\hline L.ROE & $(8.22)$ & $0.194 * * *$ & $(8.41)$ & $0.190 * * *$ \\
\hline leverage & $\begin{array}{r}0.026 * * * \\
(5.47)\end{array}$ & $\begin{array}{r}(5.45) \\
0.045 * * * \\
(2.79)\end{array}$ & $\begin{array}{r}0.026 * * * \\
(5.66)\end{array}$ & $\begin{array}{r}(5.41) \\
0.041 * * * \\
(2.72)\end{array}$ \\
\hline leverage 2 & $\begin{array}{r}-0.003 * * * \\
(-6.29)\end{array}$ & $\begin{array}{r}-0.007 * * * \\
\circ(-4.71)\end{array}$ & $\begin{array}{r}-0.003 * * * \\
(-6.47)\end{array}$ & $\begin{array}{r}-0.007 * * * \\
(-4.78)\end{array}$ \\
\hline GDPgrowth & $\begin{array}{r}0.171 * * * \\
(2.58)\end{array}$ & $\begin{array}{r}0.369 * \\
(1.78)\end{array}$ & $\begin{array}{r}0.362 * * * \\
(5.09)\end{array}$ & $\begin{array}{r}1.331 * * * \\
(5.80)\end{array}$ \\
\hline size & $\begin{array}{r}0.002 * * * \\
(2.62)\end{array}$ & $\begin{array}{r}0.027 * * * \\
(6.97)\end{array}$ & $\begin{array}{r}0.002 * * * \\
(2.72)\end{array}$ & $\begin{array}{r}0.029 * * * \\
(7.78)\end{array}$ \\
\hline crisis & $\begin{array}{l}0.001 \\
(0.58)\end{array}$ & $\begin{array}{r}-0.040 * * * \\
(-4.45)\end{array}$ & $\begin{array}{r}0.001 \\
(0.63) \\
0.010 * * * \\
(7.32) \\
\end{array}$ & $\begin{array}{r}-0.043 * * * \\
(-4.93) \\
0.038 * * * \\
(8.91) \\
\end{array}$ \\
\hline Number of Instruments & 125.000 & 82.000 & 126.000 & 83.000 \\
\hline$A R(1)$ & -13.299 & -9.280 & -13.375 & -9.249 \\
\hline AR(1) p-value & 0.000 & 0.000 & 0.000 & 0.000 \\
\hline$A R(2)$ & -0.444 & -1.504 & -0.507 & -1.588 \\
\hline AR(2) p-value & 0.657 & 0.133 & 0.612 & 0.112 \\
\hline Hansen & 40.472 & 24.310 & 38.782 & 22.487 \\
\hline Hansen p-value & 0.342 & 0.208 & 0.301 & 0.196 \\
\hline Observations & 16259 & 16259 & 16259 & 16259 \\
\hline
\end{tabular}

Notes: L.ROA: one-period lag of ROA, L.ROE: one-period lag of ROE, ROA:return on total assets, ROE:return on equity, leverage: total debts to equity, lterm: long-term debts to equity, sterm: short-term debt to equity, gdpgrowth:thegrowth rate of GDP, size:log of total assets, class: dummy variables of type of ownership structure, crisis: dummy variables of the crisis period, ${ }^{*} p<0.10,{ }^{* *} p<0.05,{ }^{* * *} p<0.01$. 
Table 4. System GMM estimation results of Equation (1) for small enterprises and mediumenterprises. In columns (1) and (2), ROA and ROE are regressed against their lag terms, leverage levels, and crisis for the state-owned SMEs. In column (3) and (4), ROA and ROE are regressed against their lag terms, leverage levels and crisis for the private SMEs.

\begin{tabular}{|c|c|c|c|c|}
\hline & \multicolumn{2}{|c|}{ State-owned enterprises } & \multicolumn{2}{|c|}{ Private enterprises } \\
\hline & $\begin{array}{r}\text { (1) } \\
\text { ROA }\end{array}$ & $\begin{array}{r}(2) \\
\text { ROE }\end{array}$ & $\begin{array}{r}\text { (3) } \\
\text { ROA }\end{array}$ & $\begin{array}{r}(4) \\
\text { ROE }\end{array}$ \\
\hline$\overline{L . R O A}$ & $\begin{array}{r}0.651^{* * *} \\
(3.53)\end{array}$ & & $\begin{array}{r}0.223^{* * *} \\
(8.36)\end{array}$ & \\
\hline L.ROE & & $\begin{array}{r}0.780^{* * *} \\
(2.83)\end{array}$ & & $\begin{array}{r}0.193^{* * *} \\
(5.37)\end{array}$ \\
\hline leverage & $\begin{array}{c}-0.004 * \\
(-1.74)\end{array}$ & $\begin{array}{l}-0.005 \\
(-0.33)\end{array}$ & $\begin{array}{r}0.026^{* * *} \\
(7.21)\end{array}$ & $\begin{array}{r}0.116^{* * *} \\
(7.47)\end{array}$ \\
\hline leverage2 & $\begin{array}{r}0.000 \\
(0.78)\end{array}$ & $\begin{array}{r}0.000 \\
(0.12)\end{array}$ & $\begin{array}{r}-0.003^{* * *} \\
(-7.94)\end{array}$ & $\begin{array}{r}-0.014 * * * \\
(-8.54)\end{array}$ \\
\hline GDPgrowth & $\begin{array}{l}-0.306 \\
(-0.83)\end{array}$ & $\begin{array}{l}-0.136 \\
(-0.12)\end{array}$ & $\begin{array}{r}0.367^{* * *} \\
(5.11)\end{array}$ & $\begin{array}{r}1.280^{* * *} \\
(4.97)\end{array}$ \\
\hline size & $\begin{array}{c}0.003 \\
(1.04)\end{array}$ & $\begin{array}{r}0.008 \\
(1.36)\end{array}$ & $\begin{array}{r}0.003^{* * *} \\
(4.99)\end{array}$ & $\begin{array}{r}0.012^{* * *} \\
(5.94)\end{array}$ \\
\hline crisis & $\begin{array}{r}0.010 \\
(0.97)\end{array}$ & $\begin{array}{c}0.072^{* *} \\
(2.13)\end{array}$ & $\begin{array}{r}0.010^{* * * *} \\
(7.29) \\
\end{array}$ & $\begin{array}{r}0.034^{* * *} \\
(7.60) \\
\end{array}$ \\
\hline Number of Instruments & 95.000 & 66.000 & 126.000 & 83.000 \\
\hline$A R(1)$ & -2.226 & -1.927 & -13.400 & -9.741 \\
\hline AR(1)p-value & 0.026 & 0.054 & 0.000 & 0.000 \\
\hline$A R(2)$ & 1.247 & 0.699 & -0.546 & -2.292 \\
\hline AR(2) p-value & 0.212 & 0.485 & 0.585 & 0.022 \\
\hline Hansen & 20.760 & 18.872 & 33.662 & 19.468 \\
\hline Hansen p-value & 0.200 & 0.155 & 0.278 & 0.185 \\
\hline Observations & 163 & 163 & 16096 & 16096 \\
\hline
\end{tabular}

Notes: L.ROA: one-period lag of ROA, L.ROE: one-period lag of ROE, ROA:return on total assets, ROE:return on equity, leverage: total debts to equity, lterm: long-term debts to equity, sterm: short-term debt to equity, gdpgrowth:thegrowth rate of GDP, size: $\log$ of total assets, class: dummy variables of type of ownership structure, crisis: dummy variables of the crisis period, ${ }^{*} p<0.10,{ }^{* *} p<0.05,{ }^{* * *} p<0.01$.

The estimation results show specific differences between state-owned and non-state-owned firms. Regarding state-owned enterprises, the linear term of financial leverage is significantly negative, while the quadratic term is not significant. The results imply that optimal capital structure does not exist for state-owned businesses. However, using more debts still hurt firm performance.

By contrast, both linear and quadratic terms of financial leverage are significant in the case of non-state-owned enterprises. Moreover, the inverted-U relationship between financial leverage and firm performance is confirmed. $\mathrm{H} 2$ is supported. The results suggest that the optimal capital structure is more relevant for non-state enterprises. The differences between the two types of enterprises may come from the fact that state-owned enterprises can receive more subsidies from the government than non-state ones. State-owned firms may have lower performance compared to the private ones Ahuja and Majumdar (1998). The state-owned businesses may have low competitiveness and high privilege, which contribute to their low incentives and performance.

\subsection{Robustness tests}

To test the robustness of the model, we replace the total leverage variable with the long-term debts to equity ratio and the short-term debts to equity ratio. The results are presented in columns (1) and (2) of Table 5 for short-term leverage, and in columns (3) and (4) of Table 5 for 
long-term leverage. The results are consistent with baseline models when we find a threshold effect of both short-term and long-term leverage on ROA and ROE.

Table 5. Robustness tests using short-term and long-term leverage. In column (1) and (2), ROA and ROE are regressed against their lag terms, crisis and leverage levels in short term for robust-test purpose. The results in column (1) and (2) are compared with results in column (3) and (4) when ROA and ROE are regressed against their lag terms, crisis and leverage levels in long term.

\begin{tabular}{|c|c|c|c|c|}
\hline & \multicolumn{2}{|c|}{ Short-term leverage } & \multicolumn{2}{|c|}{ Long-term leverage } \\
\hline & $\begin{array}{r}\text { (1) } \\
\text { ROA }\end{array}$ & $\begin{array}{r}(2) \\
\text { ROE }\end{array}$ & $\begin{array}{r}(3) \\
\text { ROA }\end{array}$ & $\begin{array}{r}(4) \\
\text { ROE }\end{array}$ \\
\hline$\overline{L . R O A}$ & $\begin{array}{r}0.235^{* * *} \\
(8.97)\end{array}$ & & $\begin{array}{l}0.245^{* * *} \\
(10.02)\end{array}$ & \\
\hline L.ROE & & $\begin{array}{r}0.182^{* * *} \\
(5.41)\end{array}$ & & $\begin{array}{r}0.186^{* * *} \\
(5.41)\end{array}$ \\
\hline sterm & $\begin{array}{r}0.026^{* * *} \\
(6.07)\end{array}$ & $\begin{array}{r}0.046^{* * *} \\
(2.60)\end{array}$ & & \\
\hline sterm2 & $\begin{array}{r}-0.003^{* * *} \\
(-6.94)\end{array}$ & $\begin{array}{r}-0.009^{* * *} \\
(-4.29)\end{array}$ & & \\
\hline lterm & & & $\begin{array}{c}0.006 \\
(1.15)\end{array}$ & $\begin{array}{r}0.103^{* * *} \\
(2.93)\end{array}$ \\
\hline lterm 2 & & & $\begin{array}{r}-0.003^{* * *} \\
(-2.61)\end{array}$ & $\begin{array}{r}-0.032^{* * *} \\
(-4.12)\end{array}$ \\
\hline GDPgrowth & $\begin{array}{r}0.378^{* * * *} \\
(5.22)\end{array}$ & $\begin{array}{r}1.356^{* * * *} \\
(5.71)\end{array}$ & $\begin{array}{r}0.390^{* * *} \\
(5.77)\end{array}$ & $\begin{array}{r}1.859^{* * *} \\
(6.42)\end{array}$ \\
\hline size & $\begin{array}{r}0.002^{* * *} \\
(2.65)\end{array}$ & $\begin{array}{r}0.028^{* * * *} \\
(7.71)\end{array}$ & $\begin{array}{r}0.004^{* * *} \\
(9.46)\end{array}$ & $\begin{array}{l}0.021^{* * *} \\
(11.45)\end{array}$ \\
\hline class & $\begin{array}{r}0.001 \\
(0.61)\end{array}$ & $\begin{array}{r}-0.040^{* * *} \\
(-5.24)\end{array}$ & $\begin{array}{c}-0.002^{*} \\
(-1.79)\end{array}$ & $\begin{array}{r}-0.019^{* * *} \\
(-3.93)\end{array}$ \\
\hline crisis & $\begin{array}{r}0.010^{* * *} \\
(7.69) \\
\end{array}$ & $\begin{array}{r}0.038^{* * *} \\
(9.30)\end{array}$ & $\begin{array}{r}0.012^{* * * *} \\
(9.29) \\
\end{array}$ & $\begin{array}{r}0.045^{* * *} \\
(9.72) \\
\end{array}$ \\
\hline Number of Instruments & 126.000 & 83.000 & 126.000 & 83.000 \\
\hline$A R(1)$ & -15.285 & -9.460 & -15.516 & -8.403 \\
\hline$A R(1) p$-value & 0.000 & 0.000 & 0.000 & 0.000 \\
\hline$A R(2)$ & -0.596 & -1.966 & 0.647 & -1.243 \\
\hline AR(2) p-value & 0.551 & 0.049 & 0.518 & 0.214 \\
\hline Hansen & 37.443 & 18.105 & 38.437 & 15.826 \\
\hline Hansen p-value & 0.296 & 0.185 & 0.312 & 0.172 \\
\hline Observations & 16259 & 16259 & 16259 & 16259 \\
\hline
\end{tabular}

Notes: L.ROA: one-period lag of ROA, L.ROE: one-period lag of ROE, ROA:return on total assets, ROE:return on equity, leverage: total debts to equity, lterm: long-term debts to equity, sterm: short-term debt to equity, gdpgrowth:thegrowth rate of GDP, size:log of total assets, class: dummy variables of type of ownership structure, crisis: dummy variables of the crisis period, ${ }^{*} p<0.10,{ }^{* *} p<0.05,{ }^{* * *} p<0.01$.

\section{Conclusions}

Using a sample of more than 4000 SMEs from Vietnam in the period 2008 - 2016, our findings prove that capital structure can affect firm performance. The paper provides micro-level evidence about the threshold effect of capital structure on firm performance for SMEs in emerging countries. This study contributes to the literature that explores the relationship between leverage ratio and firm performance in emerging and transition market like Vietnam.

To the best of our knowledge, our paper took the initiative to examine the effect of financial leverage on firm performance after the 2008 global financial crisis. We find that SMEs performance takes advantage during global financial crises due to adaptation and flexibility. Besides, we also confirm heterogeneity for different ownership types. The MM theory is the 
most appropriate in case of the state-owned businesses, while the trade-off theory can best explain the results of non-state-owned firms. This difference could be explained by the public firms receiving the support from government such as capital, interest, etc. so that they face lower financial distress and bankruptcy cost are the private ones.

Several valuable policy implications are emerging from our results. According to our results, SMEs managers should take into account various effects of debts on firm performance, such as the tax benefits, the agency and financial distress costs. Managers should maintain their firm's financial leverage at a reasonable level that balancing the benefits and costs of debts to maximize firms' profitability. Besides, public authorities should revise the role of debts in state-owned enterprises. The results show that the advantages of using debts are not present for those firms.

\section{Acknowledgements}

The authors would like to thank the editors and two anonymous reviewers of this journal for their very constructive comments that contributed to the improvement of the paper. We are solely responsible for any errors that might yet remain. This research is funded by the University of Economics Ho Chi Minh City, Vietnam.

\section{References}

Abdullah, H. and Tursoy, T. (2019). Capital structure and firm performance: evidence of Germany under IFRS adoption. Review of Managerial Science.

Abor, J. (2005). The effect of capital structure on profitability: an empirical analysis of listed firms in Ghana. The Journal of Risk Finance, 6(5):438-445. Publisher: Emerald Group Publishing Limited.

Abor, J. (2007). Debt policy and performance of SMEs: Evidence from Ghanaian and South African firms. The Journal of Risk Finance, 8(4):364-379. Publisher: Emerald Group Publishing Limited.

Adekunle, O. and Kajola, S. (2010). Capital structure and firm performance: Evidence from Nigeria. European Journal of Economics, Finance and Administrative Sciences, pages 7082.

Ahmed, N. and Afza, T. (2019). Capital structure, competitive intensity and firm performance: evidence from Pakistan. Journal of Advances in Management Research, 16(5):796-813. Publisher: Emerald Publishing Limited.

Ahuja, G. and Majumdar, S. K. (1998). An Assessment of the Performance of Indian StateOwned Enterprises. Journal of Productivity Analysis, 9(2):113-132.

Arellano, M. and Bover, O. (1995). Another look at the instrumental variable estimation of error-components models. Journal of Econometrics, 68(1):29-51.

Blundell, R. and Bond, S. (1998). Initial conditions and moment restrictions in dynamic panel data models. Journal of Econometrics, 87(1):115-143.

Cheng, Y.-S., Liu, Y.-P., and Chien, C.-Y. (2010). Capital structure and firm value in China: A panel threshold regression analysis. Afr. J. Bus. Manage., 4(12):2500-2507.

Davydov, D. (2016). Debt structure and corporate performance in emerging markets. Research in International Business and Finance, 38:299-311.

Demirgüç-Kunt, A., Martinez Peria, M. S., \& Tressel, T. (2020). The global financial crisis and the capital structure of firms: Was the impact more severe among SMEs and non-listed $\begin{array}{lllll}\text { firms? } & \text { Journal of } & \text { Corporate } & \text { Finance, } & 60,\end{array}$ https://doi.org/10.1016/j.jcorpfin.2019.101514 
El-Sayed Ebaid, I. (2009). The impact of capital-structure choice on firm performance: empirical evidence from Egypt. The Journal of Risk Finance, 10(5):477-487. Pub- lisher: Emerald Group Publishing Limited.

Fosu, S. (2013). Capital structure, product market competition and firm performance: Evidence from South Africa. The Quarterly Review of Economics and Finance, 53(2):140-151.

Fosu, S., Danso, A., Ahmad, W., and Coffie, W. (2016). Information asymmetry, leverage and firm value: Do crisis and growth matter? International Review of Financial Analysis, 46:140-150.

Gonzalez, V. M. (2013). Leverage and corporate performance: International evidence. International Review of Economics \& Finance, 25:169-184.

Guan, J., Gao, Z., Tan, J., Sun, W., \& Shi, F. (2021). Does the mixed ownership reform work? Influence of board chair on performance of state-owned enterprises. Journal of Business Research, 122, 51-59. https://doi.org/10.1016/j.jbusres.2020.08.038

Gunjati, S. B., \& Adake, C. v. (2020). Innovation in Indian SMEs and their current viability: A review. Materials Today: Proceedings, 28, 2325-2330. https://doi.org/10.1016/j.matpr.2020.04.604

Harvie, C. (2004). The contribution of SMEs in the economic transition of Vietnam. Journal for International Business and Entrepreneurship Development, 2(2):1-16. Publisher: Inderscience Publishers.

Herwadkar, Snehal, Corporate Leverage in EMEs: Did the Global Financial Crisis Change the Determinants? (December 2017). BIS Working Paper No. 681, Available at SSRN: https://ssrn.com/abstract=3088864

Jensen, M. C. and Meckling, W. H. (1976). Theory of the firm: Managerial behavior, agency costs and ownership structure. Journal of Financial Economics, 3(4):305-360.

Jo eveer, K. (2013). Firm, country and macROEconomic determinants of capital structure: Evidence from transition economies. Journal of Comparative Economics, 41(1):294- 308.

Li, K., Niskanen, J., and Niskanen, M. (2019). Capital structure and firm performance in European SMEs: Does credit risk make a difference? Managerial Finance, 45(5):582- 601. Publisher: Emerald Publishing Limited.

Lin, F.-L. and Chang, T. (2011). Does debt affect firm value in Taiwan? A panel threshold regression analysis. Applied Economics, 43(1):117-128. Publisher: Routledge eprint: https://doi.org/10.1080/00036840802360310.

Margaritis, D. and Psillaki, M. (2010). Capital structure, equity ownership and firm performance. Joürnal of Banking \& Finance, 34(3):621-632.

Modigliani, F. and Miller, M. H. (1958). The Cost of Capital, Corporation Finance and the Theory of Investment. The American Economic Review, 48(3):261-297. Publisher: American Economic Association.

Myers, S. C. (1977). Determinants of corporate borrowing. Journal of Financial Economics, 5(2):147-175.

Myers, S. C. and Majluf, N. S. (1984). Corporate financing and investment decisions when firms have information that investors do not have. Journal of Financial Economics, 13(2):187-221.

Nguyen, D. T. T., Diaz-Rainey, I., and Gregoriou, A. (2014). Determinants of the Capital Structure of Listed Vietnamese Companies. Journal of Southeast Asian Economies, 31(3):412-431. Publisher: ISEAS - Yusof Ishak Institute.

Ramli, N. A., Latan, H., and Solovida, G. T. (2019). Determinants of capital structure and firm financial performance-A PLS-SEM appROAch: Evidence from Malaysia and Indonesia. The Quarterly Review of Economics and Finance, 71:148-160.

Salim, M. and Yadav, R. (2012). Capital Structure and Firm Performance: Evidence from Malaysian Listed Companies. Procedia - Social and Behavioral Sciences, 65:156- 166. 
Vithessonthi, C. and Tongurai, J. (2015). The effect of leverage on performance: Domestically-oriented versus internationally-oriented firms. Research in International Business and Finance, 34:265-280.

Vo, X. V. and Ellis, C. (2017). An empirical investigation of capital structure and firm value in Vietnam. Finance Research Letters, 22:90-94.

Va tavu, S. (2015). The Impact of Capital Structure on Financial Performance in Romanian Listed Companies. Procedia Economics and Finance, 32:1314-1322.

Windmeijer, F. (2005). A finite sample correction for the variance of linear efficient two-step GMM estimators. Journal of Econometrics, 126(1):25-51. 